Pregledni znanstveni rad DOI: $10.17234 /$ Croatica.64.2

UDK: 821.163.42.09

821.163.42(497.6).09

821.163.42(497.6)(091)

Primljen: 13. VI. 2019.

Prihvaćen: 20. IX. 2019.

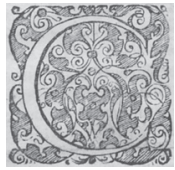

\title{
BIO(BIBLIO)GRAFIJE: POČECI ZNANSTVENOG ISTRAŽIVANJA HRVATSKE KNJIŽEVNOSTI U BIH
}

\author{
Iva Beljan Kovačić \\ Filozofski fakultet Sveučilišta u Mostaru \\ Odjel za hrvatski jezik i književnost \\ iva.beljankovacic@ff.sum.ba
}

Rad se bavi počecima znanstvenog promišljanja hrvatske književnosti u Bosni i Hercegovini te predstavlja biografska i biobibliografska istraživanja sedmorice autora, počevši od Filipa Lastrića u 18. do Tugomira Alaupovića u prvoj polovici 20. stoljeća. Promatramo kako su ovi autori razumijevali književnost i njezinu povijesnu dimenziju, osobito kako su pristupili osnovnim problemima povijesti književnosti kao što su definiranje korpusa, izbor pisaca, periodizacija, književnopovijesna interpretacija i vrednovanje te koja su rješenja ponudili. Analizira se i postupno napuštanje okvira biobibliografije te primjena složenijih književnopovijesnih pristupa.

Ključne riječi: biografija, bibliografija, hrvatska književnost u $\mathrm{BiH}$, povijest hrvatske književnosti. 


\section{HISTORIOGRAFIJA I BIOGRAFIJA}

Počeci znanstvenog istraživanja hrvatske književnosti u BiH vezani su za historiografski i biografski rad u franjevačkoj provinciji Bosni Srebrenoj, koji zamah uzima u 18. i posebno u 19. stoljeću. U 18. stoljeću, premda je i ranije u ovoj provinciji bilo kroničarskih zapisa, raste interes za povijest pa nastaje cijeli niz samostanskih ljetopisa (usp. Jelenić 1917: 3-4), od kojih su za bosansko-hercegovački prostor najznačajniji ljetopisi Nikole Lašvanina, Bone Benića i Marijana Bogdanovića. U isto vrijeme nastaje i historiografsko djelo Epitome vetustatum Bosnensis provinciae (Pregled starina Bosanske provincije, $1775^{1}$ ) Filipa Lastrića.

Interes za historiografiju dijelom je motiviran podjelom Bosne Srebrene sredinom 18. st. na dalmatinski, slavonsko-ugarski i bosansko-hercegovački dio, koju su članovi njezina bosansko-hercegovačkog dijela doživjeli kao ugrozu starih prava. Poticaj istraživanju prošlosti, kao svojevrsnom legitimiranju starine, identiteta i prava, također su i različite opasnosti uvjetovane socijalnim i političkim stanjem u osmanskoj Bosni (usp. Beljan 2011: 15-28). U interesu za prošlost očitavamo osim toga utjecaj racionalizma i prosvjetiteljstva 18. stoljeća te poimanje povijesti kao procesa u kojem čovjek aktivno sudjeluje (usp. Koselleck 1990), što se osobito ogleda u Lastrićevu i Benićevu historiografskom pristupu (usp. Beljan 2011: 146-147). Upravo se u ovim djelima nalaze prvi poticaji za znanstveno bavljenje književnom prošlošću, koje će se intenzivirati u 2. polovici 19. stoljeća.

Za ljetopise i Lastrićevu povjesticu naime možemo vezati i početke biografije u ovoj književnosti. Budući da u svoj sastav uključuju i različite dokumente i popise (usp. Beljan 2011: 25-95), ova historiografska djela donose i popise nositelja poglavarskih dužnosti u Bosni Srebrenoj (biskupa, provincijala, gvardijana i drugih dužnosnika), čija je svrha „da slijedom nositelja određene časti legitimiraju trajnost i važnost njihovih ustanova" (Gross 2001: 41). Popisi se mjestimice proširuju podacima o osobama, a tamo gdje autor ima dovoljno građe, prerastaju u biografske skice. ${ }^{2}$ Prvi biografski zapisi nastaju pod snažnim utjecajem hagiografije, ali se oblikuju i

1 Prvo je izdanje Lastrićeve povjestice izišlo u Veneciji 1765. godine pod naslovom Epitome vetustatum Provinciae Bosniensis, a u Anconi je 1776. tiskano drugo, prošireno izdanje, naslovljeno Epitome vetustatum Bosnensis provinciae.

2 Usp. Lastrić 2003: 125-136; Lašvanin 2003: 253-260, 287-295; Benić 2003: 123-124, 269, 274, 335-336. 
u okviru onodobnog shvaćanja vjerodostojnosti, odnosno uzusa oblikovanja znanstvenoga tipa teksta. Autori tako slijede svoje izvore, starije kronike i druge spise, koje drže vjerodostojnim svjedocima ispričanih događaja. ${ }^{3}$

Pritom se dā zamijetiti da u Lastrićevim biografskim skicama do izražaja više dolazi potreba za znanstvenom akribičnošću i dokumentiranjem (usp. Lastrić 2003: 126-128), a manje hagiografski elementi te potonje zamjećujemo tek u bilješkama o Petru Lašvaninu i Augustinu iz Tuzle (isto: 132-33). U Ljetopisu pak Nikole Lašvanina hagiografski su elementi najizraženiji (usp. Beljan 2011: 59-64).

Početke biografije, pa i bibliografije, iz kojih kasniji istraživači crpe podatke, mogli bismo tražiti još i ranije, u samostanskim nekrologijima (zapisima o pokojnim članovima zajednice). Premda nije riječ o zapisima narativnoga tipa,

u nekrologijima se uglavnom naznačivao datum smrti preminuloga fratra, koliki mu je bio životni vijek, koje je službe obnašao u Redu i Provinciji, a navodila su se i posebna svojstva, moralna ili intelektualna, kojima se netko odlikovao, kao što su, primjerice, činjenice da se bavio pisanjem, liječenjem, slikanjem, pomaganjem bolesnima u epidemijama, gradnjom crkve ili župne kuće, da se isticao asketskim načinom življenja i sl. (Karamatić 2015: 7).

Dakle povezan s nekrologijima, hagiografijom i historiografijom oblikuje se žanr biografije, koji se u 19. stoljeću osamostaljuje od kronika pa se kao prva samostalna biografija pojavljuje Životopis slavnoga muža Augustina Miletića (1835) Marijana Šunjića. Ubrzo se biografija udaljava i od konvencija hagiografije: u 19. stoljeću, u tekstovima koje pišu Lovro Karaula, Anto Knežević, Jako Matković, Ivan Franjo Jukić, Jako Baltić i drugi, biografija se usmjerava prema društveno-političkoj zbilji i pojedincu koji se na tom planu angažira. Premda se radi o takozvanom rubnom književnom žanru, pomnija analiza ovih biografija pokazuje njihovu usuglašenost s onodobnim dominantnim književnim strujanjima (usp. Beljan Kovačić 2017: 493-515).

U 19. st. biografija dakle postaje plodan žanr u ovoj književnosti, u kojem se okušala većina poznatih autora. Unatoč tome što svi ovi tekstovi u određenoj mjeri kombiniraju dokumentarističke i literarne postupke, može se primijetiti da se već u 19. stoljeću jasno profiliraju dvije skupine općenito

Tako životopisne podatke obojica ljetopisaca dijelom preuzimaju iz starijih rukopisa, primjerice Lašvanin iz djela Tabula od ministara i kapitula Andrije Šipračića iz 17. stoljeća. 
karakteristične za ovaj žanr (usp. Solar 2006: 42): prva okuplja tekstove koji su u obradi građe bliži literarnom, a druga one koji su bliži znanstvenom tipu biografije. Tekstovi iz prve skupine nastavljaju razvijati modele (nefikcionalne) pripovjedne proze, dok u onima iz druge skupine možemo tražiti početke znanstvenoga promišljanja ove književnosti.

Kao što i korijene povijesti književnosti nalazimo „u antičkim biografijama slavnih pisaca i osobito u radu bibliotekara helenističkog razdoblja, koji su nastojali klasificirati rukopise, izvorne tekstove odvojiti od kasnijih dodataka i sastaviti popise pojedinih djela i autora" (Solar 2006: 228), u prvim dakle bio(biblio)grafijama možemo tražiti početke znanstvenog istraživanja hrvatske književnosti u $\mathrm{BiH}$. Premda su ti počeci vezani za pokušaj popisivanja i usustavljivanja neobrađene građe, ne zaustavljaju se samo na tome. U njima zapažamo i osviještenost autora o povijesnoj dimenziji obrađenih književnih tekstova. Osim toga možemo promatrati i nastojanje njihovih autora da uspostave određene metodološke okvire za svoj rad te iznađu odgovore na pitanja koja stoje pred svakim povjesničarom književnosti, a to su - prema modelu metodološkoformacijske analize književnopovijesnih radova koji je osmislila P. Meić - problemi izbora pisaca, periodizacije, književnopovijesne interpretacije, recepcije i vrednovanja (usp. Meić 2010: 51-72). Primjenjujući taj model analize usmjeravam se na nabrojene probleme, aktualne i u današnjim istraživanjima istoga korpusa, kao i na rješenja koja pojedini istraživači nude.

Treba napomenuti i to da ovi biobibliografski radovi, premda dobrim dijelom napuštaju okvir narativne biografije, često sadrže narativne elemente, koji pokazuju i autorov odnos prema predmetu proučavanja. Vrijedno je zato kroz te elemente promotriti i autobiografsku dimenziju teksta, to jest način na koji pojedini autori u prostoru života i rada svojih prethodnika propituju vlastitu životnu ulogu.

\section{FILIP LASTRIĆ}

Filip Lastrić prvi pokazuje interes za književnu i kulturnu, a ne samo za političku i crkvenu prošlost svoje zajednice, pa svojim istraživanjem, osim provincijala, biskupa i drugih crkvenih dužnosnika, obuhvaća i pisce. U petom poglavlju Pregleda starina donosi ,popis pisaca Bosanske provincije koji su tiskali djela" (Lastrić 2003: 136-138), što predstavlja prvi pokušaj bibliografskoga rada na ovoj građi. Lastrić u svoj popis uključuje osamnaest 
pisaca počevši od Ivana Bandulavića pa zaključno do sebe, napominjući da je popis ograničen manjkom dokumenata: „Vjerojatno je, štoviše, sigurno je, da je u ovoj prastaroj provinciji bilo mnogo drugih pisaca, kao i biskupa o kojima ne znam zbog nedostatka starih dokumenata, kako sam već često napominjao" (isto: 138).

Premda rudimentaran, ovaj biobibliografski rad ipak ponešto kazuje i o Lastrićevu shvaćanju književnosti. Kao prvo uočavamo da njegov izbor pisaca obuhvaća granice Bosne Srebrene prije njezinih dioba u 18. stoljeću (premda djelo objavljuje u vrijeme kad su se dalmatinski i slavonsko-ugarski dio već odcijepili u posebne provincije). Time pokazuje da kulturu toga prostora shvaća kao jedinstvenu cjelinu, neovisno o novim granicama provincije i triju carstava na kojima se našla, odnosno pokazuje da prednost daje kulturnoj povezanosti nad teritorijalno-političkom. ${ }^{4}$ Posredno također, govoreći o recepciji djela obrađenih pisaca, pokazuje da su bili poznati i čitani na cijelom obuhvaćenom kulturnom prostoru.

Nadalje se u Lastrićevu tekstu uočavaju kratke naznake opisa djela, kao i valorizacije. Uz ime pisca i naziv djela Lastrić redovito spominje jezik na kojem je napisano (ilirski, latinski), zatim daje kratku informaciju o sadržaju i/ili žanru (propovijedi, teološki spis, gramatika, pjesme itd.), kao i izvor odakle je djelo prevedeno/prerađeno, ne propuštajući u nekoliko primjera naglasiti da je riječ o „znamenitom” (Lastrić 2003: 137) ili „poznatom” (isto: 138), dakle aktualnom djelu.

U nekoliko slučajeva Lastrić donosi i kratke vrijednosne prosudbe pisca ili djela i njegove uspješnosti. Tako će za Lovru Ljubušaka (Šitovića) reći da je ,izvrsno preveo na ilirski jezik gramatiku od Emanuela i drugih” (isto: 137), za Stjepana Vilova da je „dosjetljiv, a tokom izlaganja da je teolog koji ne zaostaje ni za najučenijima" (isto: 137). Najopširnije vrednovanje vezano je za djelo njegova suvremenika Jeronima iz Rame (Filipovića), koji je „poštovanja vrijedni otac” (isto: 138). Njegova knjižica Put križa tako po Lastriću donosi „,prekrasne upute i razmišljanja”, a u propovijedima je „divno uskladio duboku učenost s jasnim tumačenjem divno podešenu shvaćanju puka" (isto: 138). Da su Lastrićeva zapažanja o Filipovićevim tekstovima na tragu primjećivanja njihove prosvjetiteljske koncepcije i

4 Treba pritom imati na umu i poseban status Bosne Srebrene u odnosu na druge ustrojbene jedinice franjevačkog reda, te činjenicu da je zbog toga imala i određene političke atribute, a njezini je članovi doista shvaćali kao „redodržavu”, dajući toj pripadnosti prednost nad pripadnošću državno-političkom sustavu (v. o tome Džaja 1971). 
težnje za komunikativnošću, pokazuju i rezultati suvremenih studija (usp. Demo 2005).

Opširan popis s opaskama o sadržaju i žanru donosi i za svoja djela, konstatirajući za zbirku Od' uza me da „u njoj ima sabrano mnogo vrlo sažetih propovijedi, podešenih za župnike i bosanske misionare" (Lastrić 2003: 138). Sažetost, kratkoća i vođenje računa o naslovljeniku, tj. komunikativnosti i svrsishodnosti teksta, i u novije se vrijeme ističe kao oznaka Lastrićeve poetike (usp. Beljan 2014: 51-54).

Lastrićev bibliografski rad, premda naoko šturi popis osamnaest pisaca i njihovih djela, pokazuje da je prvi bosanskohercegovački historiograf prepoznavao i povijesnu dimenziju književnosti.

\section{IVAN FRANJO JUKIĆ}

Nastavljač je Lastrićeva rada u 19. stoljeću svestrani pisac i znanstvenik Ivan Franjo Jukić, čiji radovi pomažu postaviti temelje mnogih znanstvenih disciplina u Bosni i Hercegovini. Najbolji poznavatelj njegova rada, povjesničar književnosti Boris Ćorić, dijeli Jukićeve biografske od biobibliografskih radova svrstavajući prve u literarna, a druge u znanstvena ostvarenja. Literarnim tako smatra biografije istaknutih franjevaca Vice Vicića, Mihovila Čuića, Nikole Ogramića, Jurja Dobretića (Dragišića) i Mate Benlića, a znanstvenim djelom tekst Književnost bosanska (usp. Ćorić 1973: 70, 80-86).

Ćorić razdiobu očito pravi prema postojanju ili odsutnosti narativnog elementa u ovim tekstovima, na sličan način kako sam na početku ovoga rada podijelila sve tekstove biografija u književne i znanstvene. U prvoj skupini koju Ćorić izdvaja tako imamo narativne biografije, ponekad i s određenom dozom pripovjedačke napetosti, primjerice u tekstovima o Benliću i Ogramiću (usp. Jukić 1973: 41-43, 244-247). Priče o životima biskupa Benlića i Ogramića, preuzete iz starijih izvora, u podlozi zadržavaju hagiografski životopisni model, kao i u Lašvaninovim životopisima istih osoba.

S druge strane u radu Književnost bosanska Jukić donosi kratke biobibliografije starijih pisaca od Matije Divkovića do Franje Sitnića, zasnivajući ih na istraživanju arhivske i druge građe, s podacima o izdanjima i s kratkim opisom žanrovskih, sadržajnih i drugih elemenata (usp. Jukić 1973: 48-56, 254-261). Koliko je u tome bio znanstveno precizan, potvrđuje i jedan od ponajboljih nastavljača njegova rada u 20. st., akribični biobibliograf Anto Slavko Kovačić, koji konstatira: „Njegovi biobibliografski podaci su toliko 
pouzdani da ih se sa sigurnošću i danas može upotrebljavati” (Kovačić 1991: 17).

Međutim može se primijetiti da je i u prvoj - narativnoj - skupini Jukićevih biografija primjetan ovaj znanstveni pristup. Kad sastavlja biografije osoba iz 17. st. za koje nema dovoljno pouzdanih dokumenata (Benlić i Ogramić), oslanja se na podatke legendarne provenijencije kako bi rekonstruirao što potpuniji životopis, ali ih i ovdje preuzima iz starijih izvora - kroničara Nikole Lašvanina i Stjepana Margitića te povjesničara Danielea Farlatija (isto: 41, 246-247). Osobito je taj pristup očit u biografiji čuvenoga humanista Jurja Dragišića. U njoj Jukić prema dostupnoj građi oblikuje biobibliografiju, donosi i kratak pregled literature o Dragišiću, a na recepciju se njegova djela osvrće i citirajući pohvalne stihove koje su o njegovim djelima napisali poznati Dubrovčani Damjan Benešić, Ilija Crijević i Karlo Pucić (isto: 479-484).

Rad Književnost bosanska, objavljen 1850. i 1851. godine u dvama nastavcima u II. i III. knjizi časopisa Bosanski prijatelj, koji je Jukić pokrenuo i uglavnom sam uređivao i ispunjavao prilozima, najvažniji je za upoznavanje njegova pogleda na književnost. Detaljnija analiza pokazuje da ovo nije samo biobibliografski rad, nego rudimentaran nacrt povijesti književnosti, odnosno njezine „tradicionalne pozitivističke književnopovijesne podvrste” (Meić 2010: 84-86). Jukićeva su znanstvena načela utemeljena u historizmu i biografizmu 19. stoljeća. Koncentriran je na skupljanje i kategoriziranje činjenica vezanih za pisce, djela, rukopise, izdanja.

Međutim u strukturi je rada uočljivo da Jukić najprije pravi uvod popisu pisaca, u kojem donosi i prijedlog periodizacije. Tako u prvom dijelu rada polazi od srednjovjekovnog perioda, koncentrirajući se pretežno na rukopise i na njihovu (ne)proučenost u struci. U radu se oslanja na dokumente i na suvremenu literaturu o predmetu, spominjući u bilješkama vlastita istraživanja arhiva i knjižnica, zatim srednjovjekovne spise prikupljene i tiskane u 19. st., Katančićev rad i druge izvore.

Zatim prelazi na raspravu o književnosti od 16. do 19. stoljeća, za koju konstatira da je bolje sačuvana i dokumentirana, posredno pokazujući i da je promatra kao novi segment književnosti s drukčijim obilježjima od srednjovjekovnih. Usmjerava se osobito na ćiriličku grafiju i njezine posebnosti, potvrđene u sačuvanim knjigama. Zatim uspostavlja klasifikaciju pisaca ovoga razdoblja odlučujući se upravo za podjelu prema pismu: „pisaoci, koji su azbukom pisali” (Jukić 1973: 51) i „,pisaoci, koji su abecedom pisali" (isto: 254). Pritom ne ide samo za mehaničkom podjelom nego iznosi 
mišljenje da su se pisci koji su pisali latinicom „,ugledavali na književnike dubrovačke, dalmatinske i slavonsko-ugarške, koji su gotovo samo latinskim slovima služili se, a to se i od tuda vidi, što su se i njihovog pravopisa i načina pisanja dèržali" (isto: 254). Time pokazuje određene naznake prepoznavanja poetičkih razlika, makar na grafijskoj i pravopisnoj razini. Unutar tih dviju skupina, što je indikativno, ne odlučuje se za abecedni biobibliografski poredak pisaca, nego za kronološki - književnopovijesni pozitivistički.

Ovaj dio spisa Jukić dakle strukturira tako što kao najmanju jedinicu uzima autorski opus. U prvoj skupini, među autorima koji su pisali azbukom, obrađuje tako četiri pisca: Matiju Divkovića, Stjepana Matijevića, Pavla Posilovića i Stjepana Markovca Margitića. U drugoj skupini, latiničkoga pisma, predstavlja četrnaest pisaca: Ivana Bandulavića, Ivana Ančića, Lovru Šitovića, Marijana Lekušića, Jeronima Filipovića, Marka Dobretića, Filipa Lastrića, Vicu Vicića, Grgu Ilijića (Varešanina), Augustina Miletića, Stjepana Marjanovića, Ambroza Matića, Rafu Barišića, Mihovila Čuića i Franju Sitnića.

Jukićev izbor pisaca, kao i Lastrićev, ne ograničava se na bosanski i hercegovački dio provincije, nego i na pisce koji su nakon podjele ostali u dalmatinskom dijelu (L. Šitović, J. Filipović), iz čega se vidi da je svijest o jedinstvenosti ove kulture vitalna i u 19. stoljeću. Zadržava se i kod nastavljača Jukićeva rada.

U obradi pisaca Jukić se naizgled drži biobibliografskoga načela, ali primjećujemo i ovdje elemente složenijega književnopovijesnog pristupa. Najprije donosi kratku biografiju, a u nekim slučajevima, kao za Matiju Divkovića, rekonstruira podatke iz samih njegovih knjiga i dostupne literature (usp. Jukić 1973: 51). Zatim popisuje i opisuje djela, dajući (u mjeri u kojoj uspijeva pronaći informacije) vrlo detaljne i akribične podatke o naslovu, posveti, tisku, sadržaju, izdanjima. Donosi podatke i o pojedinim neobjavljenim rukopisima. ${ }^{5}$

Uz (p)opise djela i biografske podatke o piscima Jukić donosi i poneki podatak o recepciji. Za starije pisce, koji su pisali bosančicom, donosi ga neizravno, u završnoj konstataciji o manjku dokumenata i rukopisa za podrobniju rekonstrukciju književne prošlosti. Rukopisa, tako veli Jukić:

\footnotetext{
5 Za neke rukopise napominje da se nalaze kod njega, primjerice za Margitićeve Homilije,
} Likarušu i Kroniku (Jukić 1973: 55). 
moguće je, da je i više bilo, al poginulo, osobito bilo je rukopisah u fojničkoj bibl., a bibliotekari neznajući ih štiti i cieniti, sažgaše ih. Za čudo je, da štampanih knjigah ilirskih u bibliotekama francisk. samostanah od lieka, tako rekavši, neima, a talianskih, latinskih, niemačkih, francuskih i t. d. preko reda! Ja sam ove knjige sebi odkupio, sve od prostih ljudi, a još ih se i poderanih nalazi, koje oni čitaju; knjige ove ne samo da su čistim bosanskim jezikom pisane, već i potrebite stvari duhove liepo uče (isto: 55).

Zatim najavljuje kako će dijelove tih knjiga pretiskati „za ugled i gramaticima i redovnicima današnjim: pèrvi da nauče čisti jezik, a drugi, da se okane mlitavosti, već da sliede svoje stare otce, prihvate za pero, te narod svoj izdavanjem koristnih knjigah na pravu stazu krieposti izvedu!" (isto: 56 ).

Citirani odlomak puno govori i o njegovu iznimnom trudu oko skupljanja rukopisa i podataka o njima, kao i o tom da njegovi suvremenici nemaju jednako razvijenu svijest o kulturi kojoj pripadaju. Iščitavamo to iz napomene da rukopisa na ilirskome jeziku nema u samostanima, nego ih on otkupljuje od ,prostih ljudi”, što nam posredno govori i o recepciji djela Divkovića, Margitića i drugih starih pisaca. Osim što nam ovaj dio donosi podatke o recepciji djela starijih pisaca, čiji su se rukopisi u 19. st. „poderani”, dakle korišteni, nalazili kod „prostih ljudi”, ali ne i u samostanskim knjižnicama, ovaj odlomak sadržava i Jukićev sud o vrijednosti tih pisaca, koje ističe kao uzor suvremenicima. Sličnu vrijednosnu prosudbu iščitavamo i u dijelu gdje govori o Pištolama i evanđeljima Ivana Bandulavića, konstatirajući da su ,služile kod božje službe za porugo stolietje, dok Knežević iste knjige nije pod svojim imenom izdao, tobože mnoga popravio, al uprav govoreći pokvario" (isto: 254).

Jukić dakle izravno i neizravno vrednuje pisce i djela. Neizravno o vrednovanju pojedinog pisca možemo zaključiti i po prostoru koji je dobio u tekstu. Primjetno je pritom da više prostora daje piscima koji su pisali bosančicom, osobito pak Matiji Divkoviću, čime im priznaje ulogu začetnika ove tradicije. Od kasnijih pisaca najviše prostora daje Filipu Lastriću.

Vrijednosne procjene Jukić donosi i ocjenjujući osobu i sposobnosti samog autora, pa će tako za Filipovića konstatirati da je „čoviek vèrlo učen i dobar redovnik”, ali i da su „knjige njegove čistim jezikom pisane, slog dobar i razabran" (isto: 257). Učenost i bogoljubnost veže i za Lovru Šitovića (isto: 256) i Augustina Miletića (isto: 259), a osobito pak za Filipa Lastrića, kojeg drži jednim od „najzaslužnijih franciskanah bosanskih za provinciu i književnost" (isto: 258). Ocjenjuje i njegov Nediljnik dvostruk, homiletičku 
zbirku, „to jest po dva govorenja za svaku nedilju priko godine, lasna, kratka i ravna samo za lastnoćju pastirah naseljačkie puka priprostoga i nenaučenoga, uredjena" (isto: 258). Tom konstatacijom ukratko opisuje Lastrićevu poetiku, kratkoću i sažetost teksta, prosvjetiteljske utjecaje, komunikativnost i vođenje računa o konkretnom recipijentu. Uočljivo je također da Jukić kao jednu od najvećih vrijednosti knjiga izdvaja jezik: ,čisti jezik” (isto: 65, 257).

Jukić tako, moglo bi se reći, oblikuje kratak nacrt povijesti hrvatske književnosti u Bosni i Hercegovini. Taj je nacrt pozitivistički koncipiran, u prvom redu usmjeren na činjenice vezane za živote autora i izdanja djela. Ali donosi i prijedlog periodizacije, izbor pisaca u kojem se uvažava jedinstvenost kulturnog prostora nekadašnje Bosne Srebrene, započinje problematizirati pitanja jezika i pisma, recepcije, dostupnosti i obrađenosti građe, a u kratkim naznakama i poetičkih osobitosti pisaca, pa i književne vrijednosti pojedinih djela.

U Jukićevim tekstovima dominira racionalni odnos prema svijetu i znanstvena akribičnost, ideal objektivnosti pozitivističkoga tipa. Njegova je motivacija dokumentirati, popisati i obraditi ono što je nepoznato i što se iz različitih razloga prije njega nije uradilo: „nepovoljne okolnosti, oli neprepustiše sve popisati, ali ako bi popisano, neučuvaše do nas!" (isto: 41). Primjetno je također da u tekstovima oblikuje osobit model života za nasljedovanje, kao jedan od ciljeva biografskog pisma, a to je čovjek znanja i kulture. Jukiću naime nije u središtu zanimanja crkvena služba (koja se ističe u starijim biografijama ove književnosti), nego u prvom redu književni, znanstveni, kulturni rad.

U uvodu biografije čuvenoga humanista Jurja Dragišića tako čitamo zanimljive rečenice koje govore o motivaciji Jukićeva rada, ali i o načinu na koji doživljava svoju ulogu u zajednici te kroz biografije drugih problematizira vlastiti život. Tako on piše: „Europa nas drži za neuke i za neprikladne - poludivje ljude, neobzirući se na naše tužne okolnosti”, osmansku vlast koja „,̌etiri stoljetja zaklanja i krije, da nam svjetlost naukah i umjetnosti neograne” (isto: 479). Želeći pokazati da su ljudi njegove zemlje u pravim okolnostima jednako sposobni, ali također i vratiti od tuđinaca ,prisvojene" ugledne ljude (isto: 479), sastavlja životopis J. Dragišića, kao i drugih znamenitih pripadnika vlastite zajednice. Želja za znanošću, umjetnošću, prosvjećivanjem te pogodnijim okolnostima za razvoj duha može se čitati i kao Jukićevo propitivanje vlastite pozicije čovjeka znanja, velikog entuzijazma i građanske osviještenosti u okolnostima tome posve nesklonima i nedoraslima. 


\section{GRGO MARTIĆ}

Martićev članak Bosanska i hercegovačka književnost, objavljen 1844. godine, izlazi iz slijeda opisanih radova jer nije utemeljen na biobibliografskom postupku. U njemu Martić nastoji donijeti kratak pregled kulturnih i prosvjetnih prilika u Bosni i Hercegovini u četiri stoljeća, i to i u katoličkoj, pravoslavnoj i islamskoj zajednici. Međutim potonja dva segmenta bosanskohercegovačke kulture obrađuje sasvim šturo (pravoslavni), donoseći općenite i dosta negativne ocjene (muslimanski), da bi katolički segment obradio nešto detaljnije.

Struktura Martićeva rada, u kojoj se iscrtavaju opće kulturne prilike, obrazovanje, književni i znanstveni rad u BiH te nabrajaju važniji pisci i djela, u osnovnim se točkama podudara s nacrtom književnopovijesne studije pozitivističkoga tipa. Međutim ipak se ne može tako okarakterizirati jer su njegova zapažanja ostala na razini skice, utemeljene više na prisjećanju podataka koje poznaje i na osobnim dojmovima o predmetu, a manje na istraživanju građe. Martićeva nesklonost znanstvenom, a očito veća sklonost pripovjedačkom postupku, ogleda se i u naglašenoj subjektivnosti kazivača i prekidanju izlaganja emotivno intoniranim žaljenjem nad teškim i za obrazovanje i književnost posve nepovoljnim prilikama.

Da je Ivan Franjo Jukić književnu prošlost poznavao i istraživao daleko više od svojih suvremenika, pokazuje i ovaj Martićev rad koji o književnosti donosi iznenađujuće siromašne i nepotpune podatke. Konstatirajući da su se mnogi pripadnici njegove zajednice u prošlosti prihvaćali pisanja, s velikim troškom u Mlecima tiskali pobožna djela te ih besplatno širili u narodu, on tako spominje „nekog”, Divkovića i Margitića:

Između ostali(h) (neizvjesno velim) odlikovali su se od vijeka 17. njeki Divković iz Jelašak i Margitić od Jajca, koji(h) se djela jošt podrpana i začađila u narodu nalaze. Prvog imam pri ruci Molitvenik a) bez prvi(h) listova, zato godinu razaznati ne mogu, a posljednjeg Predike od god. 1708. Imao sam također i njegov Molitvenik, onaj fantastičeskij njegov proizvod Stjepanuše među pukom narečene, kog je bl. uspomene ep. Miletić gdjegod je koji primjerak našao sažeći dao, (i s kojim dan-danas dalmatinski knjigotršci višeput latinskim pismenima prištampanim ćare). Pala mi je šaka jošte bila Nauka hr. od g. 1611, uprav se ne opominjem od kog, ako ne od Divkovića. O ove struke spisateljima, kako također i o početku i zabačenju one bosanske bukvice kad budem bliže izvora neću lijen biti sto spriopštiti (Martić 1990: 163).

Od onih pak koji su pisali latinicom zna za trojicu starijih - Luku Vladimirovića, Lovru iz Ljubuškog (Šitovića) i Filipa Lastrića - a od novijih 
za Augustina Miletića, Stjepana Marijanovića i Ambrožu Matića, te još za anonimno djelce nepoznatoga F. G. (Franje Gracića). „I s ovim zaključujemo književnost našu kroz četiri stoljeća obdjelavanu!" (isto: 164).

Martićev pregled pokazuje dakle da su u 19. stoljeću među pripadnicima franjevačke zajednice vrlo slabo poznavali pisce 17. i 18. stoljeća. Martić nagađa i o naslovima i autorima, ali konstatira da su se te knjige još nalazile u narodu, dapače pretiskavale latinicom u Dalmaciji i prodavale. Također nam donosi informaciju da su prosvjetiteljski nastrojeni pisci 19. st. (Miletić) Margitićeve knjige uništavali, što zorno govori o promjeni kulturnoga svjetonazora kod ovih pisaca u 19. stoljeću. ${ }^{6} \mathrm{U}$ cjelini gledano Martićev članak pokazuje iskorak iz biobibliografije prema književnopovijesnoj studiji koja je, ipak, ostala vrlo štura skica.

\section{MIJO VJENCESLAV BATINIĆ}

Jukićev koncept dokumentiranih biografija koje istodobno zadržavaju narativnu formu i zanimljivo pripovijedaju o svom predmetu, primijenjen u manjoj skupini njegovih narativnih biografija, a osobito u biografiji Jurja Dragišića, nastavlja koncem 19. i početkom 20. st. razvijati Mijo Vjenceslav Batinić. Taj angažirani istraživač kulturne i crkvene povijesti, koji je u svojim djelima ,započeo intenzivnije proučavanje franjevačke prošlosti na tlu Bosne i Hercegovine" (Vešara 1982: 345), 1883. godine objavljuje Životopis fra Augustina Miletića, biskupa daulijskoga i namjesnika apostolskoga u Bosni i Hercegovini, a 1913. godine djelo Franjevački samostan u Fojnici od stoljeća XIV.-XX., u kojem donosi i kratke biografije znamenitih pripadnika te zajednice. U svom najznačajnijem djelu Djelovanje franjevaca u Bosni i Hercegovini za prvih šest viekova njihova boravka u trećem svesku, objavljenom 1887, donosi i bibliografske bilješke za dvadeset jednog pisca.

Životopis Augustina Miletića uklapa se u plodnu biografsku i hagiografsku tradiciju, ali u Batinićevu pristupu dolazi do izražaja njegova povjesničarska vokacija: teži preglednoj prezentaciji građe, inzistira na dokumentarnosti i u naraciju umeće prijepise pisama, potkrepljuje konstatacije arhivskim dokumentima (usp. Batinić 2015: 143-144). Miletićev život obrađuje u širokom socijalnom i političkom kontekstu. S druge strane lite-

6 O tom govori i Boris Ćorić, v. bilj. 16. u ovom radu. 
rarni je element nerazdvojiv dio Batinićevih biografija: karakterizira ih čvrst narativni slijed, oblikovanje zanimljive priče o nečijem životu, emocionalno angažirani pripovjedač koji pribjegava ekspresivnim retoričkim figurama i pripovjednim komentarima. Izrazit apologetski odnos prema vlastitoj zajednici, koji registriraju svi istraživači Batinićeva djela, također se artikulira pomoću spomenutih literarnih konvencija. Boris Ćorić stoga zamjećuje da je Batinić ,povijesnim činjenicama dao prigušeni sjaj patrijarhalnog shvaćanja života i pripovijedanja" (Ćorić 1979: 32).

Kao i kod Jukića, i kod Batinića se interes za prošlost izražava kao patriotska misija i vlastiti doprinos zajednici. Interes za povijest u svrhu buđenja osjećaja kolektivne pripadnosti, jačanje ideje o oslobođenju naroda, izražena tendencija k socijalnim temama, minuciozne analize socijalno-političke situacije pod osmanskom vlašću te pozitivistička akribičnost pokazuju usuglašenost njegovih tekstova s književnim i znanstvenim težnjama 19. stoljeća. Ideal života za nasljedovanje i uzor koji se predstavlja čitatelju u Jukića i Batinića postaje čovjek znanja, u širem smislu iznimni, daroviti pojedinac sposoban da na različitim poljima promijeni i unaprijedi život svoje zajednice.

U spomenutom djelu Franjevački samostan u Fojnici od stoljeća XIV.-XX., u poglavlju Znamenitija braća ovoga samostana, Batinić donosi kratke životopise članova fojničke zajednice koji su se istaknuli na različitim područjima javnog djelovanja, ili su pak bili na glasu zbog pobožna načina života. Među njima obrađuje i nekoliko pisaca: Stjepana Margitića, Nikolu Lašvanina, Marka Dobretića, Vinka (Vicu) Vicića, Augustina Miletića, Franju Sitnića, Marijana Jakovljevića, (Ivana) Franju Jukića i Bonaventuru Perišića.

Batinić životopise uglavnom ne koncipira prema strogoj biografskoj formi - krećući se od rođenja do smrti - nego u prvi plan stavlja ono u čemu se određeni pojedinac „odlikovao”, ,istaknuo”. Za Margitića tako veže „učenost", tiskanje nabožnih knjiga, ali i kroničarski rad i govornički dar (Batinić 2015: 170). Za Lašvanina veoma opsežno znanje i vještinu u upravi, kao i predanost kroničarskom radu (isto: 171). Marko Dobretić „spisao je hrvatsku moralku” (isto: 173), Vice Vicić „hrvatske pjesme za sve blagdane” (isto: 174), Franjo Sitnić propovijedi (isto: 179), kao i Marijan Jakovljević, koji je k tomu „neprestano radio, da se mladež bolje naobrazi, uvezivao joj knjige i prepisivao učila, koja bi joj manjkala" (isto: 180).

Najopširnije Batinić predstavlja rad Augustina Miletića, Bonaventure Perišića i Ivana Franje Jukića. Bonaventuru Perišića izdvaja zbog iznimne 
učenosti: „Nijedna svjetska ni bogoslovna znanost nije bila, a da se nije njome ozbiljno bavio te je postao živom enciklopedijom za svu braću u svim pitanjima svjetske ili bogoslovske struke" (isto: 185). Djela mu spominje uopćeno: „Ostavio nam je silu spisa, među ostalim latinsku crkvenu povijest i naputak urediti narodni muzej" (isto: 185). U ocjeni Miletićeva rada zadržava se uglavnom na njegovu crkvenom i društvenom djelovanju, ali mu nabraja i pisana djela. Jukića izdvaja zbog tragične uloge u političkim događajima, ali i zbog književnoga rada, nabrajajući neka od njegovih djela.

U trećem svesku djela Djelovanje franjevaca u Bosni i Hercegovini za prvih šest viekova njihova boravka, obrađuje dvadeset i jednog autora ${ }^{7}$, ali zadržavajući se u okviru bibliografije i popisujući njihova djela. Donosi i neke podatke o procesu tiskanja djela, njihovu širenju i publici (Batinić 1887: 106-107), ali vrlo uopćeno u kontekstu apologetskoga odnosa prema povijesnoj ulozi svoje zajednice, koji obilježava čitavo djelo.

Premda Batiniću u fokusu interesa nije (samo) književni rad nego cjelokupno djelovanje osobe koju drži znamenitom, i premda se uglavnom ne upušta u detaljnije analize opusa, svojim biografijama i bibliografijama zasigurno doprinosi (i) razvoju znanstvene misli o književnosti.

\section{JAKO MATKOVIĆ}

U 19. se stoljeću intenzivira rad na bibliografijama. U Hrvatskoj Ivan Kukuljević sastavlja dobar broj biobibliografija hrvatskih pisaca s područja Bosne i Hercegovine, a „mariborski biskup Mihael Napotnik prvi je sastavio najkompletniju biobibliografiju bosanskohercegovačkih spisatelja, uključivši u nju 24 člana Bosne Srebrene" (Kovačić 1991: 17). ${ }^{8}$

U samoj Bosni i Hercegovini Jukićev rad na biobibliografijama koje napuštaju narativni okvir nastavlja koncem 19. stoljeća Jako Matković u svom djelu Bibliografia bosanskih franjevaca (1896). Interesantno je da se

7 To su Stjepan Margitić, Lovro Šitović, Marijan Lekušić, Jeronim Filipović, Lovro Bračuljević, Nikola Kesić, Tomo Babić, Antun Bačić, Stjepan Badrić, Stjepan Vilov, Luka Čilić, Jeronim Lipovčić, Antun Papušić, Luka Karagić, Josip Janković, Josip Mihić, Emerik Pavić, Filip Lastrić, Marko Dobretić, Grgo Ilijić i Vice Vicić. Primjetno je da i Batinić u svoje djelo uključuje pripadnike Bosne Srebrene u nekadašnjem opsegu, dakle i sa slavonskog i dalmatinskog dijela provincije, kao i njegovi prethodnici.

8 Zbog ograničenja prostora u jednom radu, u ovo razmatranje uključujem samo biobibliografska djela koja su se pojavila u samoj Bosni i Hercegovini. 
Matković potvrđuje i kao pisac narativne biografije - Životopisa o. Jakova Baltića - u kojoj, spajajući elemente kronike i biografije te izrazito subjektivni model pripovijedanja, stvara dojmljivu i sugestivnu prozu (usp. Matković 2015). S druge strane u Bibliografiji napušta taj narativni okvir i oblikuje posve drukčiji tip teksta.

Matkovića motivira uvid da je dobar dio ove književne građe još nepoznat i neobrađen ili u rukopisu: „I ovo su nam najstariji književnici, koji su bosanicom svoja djela pisali, do danas poznati, i s njimi moramo biti zadovoljni, dok još koji na javnost ne izbije iz onih rimskih arkiva, gdje se mnogi zaista kriju" (Matković 1896: 12). Vodeći se željom da rasvijetli nepoznato, u svom djelu proširuje dotadašnje biobibliografske radove i predstavlja šezdeset autora. Odlučuje se za abecedni raspored čime dosljedno realizira model biobibliografije.

Njegov je izbor veoma obuhvatan: kao i Lastrić i Jukić, obrađuje sve pisce iz Bosne Srebrene, uzevši u obzir njezin opseg prije podjela. K tomu im dodaje i pisce s hrvatskoga prostora koji je pripadao zajedničkoj franjevačkoj provinciji prije diobe 1514. na provinciju Bosnu Srebrenu i Bosnu Hrvatsku (Franju Glavinića, Ivana Tomku Mrnavića, Sebastijana Frankovića). Time pokazuje svoje shvaćanje kulturnoga konteksta, povezanosti i utjecaja, ali je sigurno motiviran i željom za potvrdom povijesne važnosti svoje provincije. ${ }^{9}$

U svakoj jedinici svoje biobibliografije, dakle za svakog pisca, Matković donosi kratke biografske podatke i popis djela s komentarima o izdanjima, ali i podatke o nepotvrđenim izdanjima, kao i o rukopisima. Služi se podacima do kojih je mogao doći, često napominjući da su nepotpuni. Popise djela ostavlja nepotpunima i kod nekih suvremenih pisaca, koji već objavljuju u periodici. Tako primjećuje da je Martin Nedić „pisao mnogo, ali ću ja samo pokušati glavnija njegova djela iztaknuti” (Matković 1896: 44), a nepotpunu bibliografiju iznimno produktivnoga Grge Martića opravdava riječima: „Tko bi sabro pljevu, koju vjetar raznese, taj bi sabro i sva djela Fra Grge Martića" (isto: 39).

Matković zadržava određene pripovjedačke elemente u kratkim biografijama, gdje se emotivan odnos autora (ali dijelom i njegovo shvaćanje konvencije takvog rada) očituje u karakterizacijama obrađenih pisaca i u pohvalnim izrazima vezanima za njihovu osobnost. Tako vrlo često izražava

9 Ovakvom će se izboru pisaca u 20. st. usprotiviti Julijan Jelenić u svojoj Bio-bibliografiji (usp. Jelenić 1925: XI), ali i njegovo će nazivlje i izbor pisaca biti kritiziran, o čemu više riječi u nastavku ovoga rada. 
pohvalan sud o samoj osobi pisca te o važnosti njegova pisanja ili javnog angažmana. ${ }^{10}$

Vrednovanje je uglavnom prigodne/konvencionalne i pohvalne naravi, ali Matković često izražava zapažanja o poetici, recepciji djela ili mjestu autora i opusa u književnoj tradiciji. Tako je Tomo Babić ostavio „prekoristno i jako poučno djelo” (isto: 14), Knežević je „mnogo radio i dobre izvore rabio” (isto: 31), Lastrić spada „medju prve spisatelje bosanske” (isto: 33), Martić ,zauzima prvo mjesto medju hrvatskim književnicima, da, 'Homer hrvatski’ je punim pravom nazvan” (isto: 39), a Martin je Nedić „bio pravi pučki pjesnik, s toga je narod njegove pjesme rado imao i čitao" (isto: 44).

\section{JULIJAN JELENIĆ}

Rad na znanstvenoj obradi hrvatske književnosti u Bosni i Hercegovini u formi biobibliografije nastavlja u 20. stoljeću jedan od najboljih ,istraživača i poznavalaca kulturne povijesti Bosne uopće" (Džaja 1974/75: 184), produktivni povjesničar Julijan Jelenić. Srećko Džaja zapaža da je Jelenićevo pozitivističko shvaćanje historiografije kao „znanosti o činjenicama” našlo svoj izraz (i) u leksikografskom poslu (Džaja 2008: 146).

U vrijeme dok Jelenić piše svoja djela biobibliografska istraživanja više nisu dominantan način izučavanja književnosti, nego se već pišu književnopovijesne studije, a i Dragutin je Prohaska 1911. objavio svoje - kritizirano, ali ipak sintetsko - književnopovijesno djelo Das kroatisch-serbische

10 Tako o Divkoviću govori kao o „vrlom mužu i bogoljubnom redovniku te nenadkriljivom radiši” (isto: 9), o Posiloviću kao o čovjeku ,po duhu božjem i pozvan(u) od Boga da svoj narod vodi stazom spasa” (isto: 12), o Rafi Barišiću kao ,učevnu i pametnu” (isto: 17). Ančić je „skroman ali veoma učen redovnik” (isto: 13), a Mijo Batinić, „kako je skroman od naravi, skromno je i radio, te se je od jedanput kano zviezda na književnom obzorju pokazao, pak je sve djelo za djelom, jedno od drugog zanimljivije, objelodanjivao, u kojima je krasno ocrtao djela i patnje franjevaca i puka u Bosni i Hercegovini” (isto: 18-19). Mihovil Čuić bio je „dobar i pobožan redovnik” (isto: 21), Marijan Jakovljević bio je „pravim pastirom i otcem svoga naroda” (isto: 27), Blaž Josić je „vrstni latinski pjesnik” (isto: 28), Ivan Franjo Jukić „narodni mučenik” (isto: 29), Lastrić „vrstan redovnik i veliki borac za prava svoje provincije” (isto: 33), Šitović je „naučan i bogoljuban redovnik” (isto: 35), Miletić „učevan, a poniznost ga je resila i svakomu preporučivala” (isto: 42), Ignacije Strukić „mlad ali skroman, gorljiv i veoma sposoban redovnik, istom se je pokazao na književnom polju, ali svakako s velikom nadom da će spadati jednom medju prve naše hrvatske književnike” (isto: 49). Marijan Šunjić je pak „riedki učenjak” i znalac jezika, njegove su „vrline ne opisive, njegov trud za crkvu i red je ne naplatljiv; njegove su patnje za narod ne izrecive” (isto: 51 ). 
Schrifttum in Bosnien und der Herzegowina, u kojem, ,inauguriše izvjestan estetski poredak u mišljenju o literaturi”" (Bogavac 1979: 83). Već se u kritikama Jelenićeve Kulture iznose zapažanja da treba početi pisati povijest književnosti, a ne bibliografije (Ćorić 1979: 20).

Jelenićeva se proučavanja književnosti kreću uglavnom u biobibliografskim okvirima, a njegov se rad može promatrati i kao svojevrsna granica u književnopovijesnim istraživanjima hrvatske književnosti u BiH: riječ je o vrhuncu biografske i bibliografske tradicije nastale na prostoru provincije Bosne Srebrene, ali i o vremenu kad ona prestaje biti osnovni književnopovijesni pristup. Povijest književnosti već se za Jelenićeva vremena počinje oslanjati na složenije metodološke modele. Biobibliografski radovi nakon njega samo su jedan od segmenata književnopovijesnih istraživanja, a kreću se u metodološki osuvremenjenu okviru.

Rezultati Jelenićevih istraživanja književnosti izloženi su u djelima Bio-bibliografija franjevaca Bosne Srebreničke (1925) te Kultura i bosanski franjevci I. i II. (1912. i 1915), s tim da i ovo potonje istraživači promatraju (i) kao bibliografsko djelo (usp. Harni 2008: 217-233). Jelenićev je biobibliografski rad osim toga rezultirao i brojnim leksikografskim i enciklopedijskim natuknicama (usp. Džaja 2008: 146).

Djelo Bio-bibliografija franjevaca Bosne Srebreničke obuhvaća dva sveska. Prvi, objavljeni svezak, obrađuje pedeset i četiri osobe - pisce, kulturne i prosvjetne radnike - od Ivana Ančića do Blaža Josića, abecednim redom (točnije pedeset i tri pisca te ,,anonimce”, odnosno šest djela neutvrđenih autora, usp. Jelenić 1925: 5-7). Izbor pisaca Jelenić sužava u odnosu na Matkovićev, kojem u uvodu spočitava uključivanje pisaca poput Mrnavića, Glavinića, Frankovića i drugih u svoje bibliografsko djelo. Jelenić smatra da treba izostaviti čak i kod svih uključenog Jurja Dragišića (usp. isto: XI). Pisce s nekadašnjeg dalmatinskog dijela Bosne Srebrene, kao i sa slavonskog i koncem 19. st. odcijepljenog hercegovačkog, uključuje u svoje djelo držeći ih pripadnicima iste kulturne cjeline, ali zaključno do godina odcjepljenja određene nove provincije. Tako primjerice uključuje hercegovačke autore do $1846 .^{11}$

Jelenić dakle započinje problematizirati dotadašnji način izbora pisaca, ali i njegov je izbor problematiziran u stručnoj literaturi. Prigovori su naj-

11 Boris Ćorić ovaj kriterij izdvaja kao jedan od nedostataka Jelenićeva pristupa, držeći da je šteta po ukupnu sliku kulture toga vremena što Jelenić nije obradio kulturni rad u Hercegovini u vrijeme ilirskog pokreta (usp. Ćorić 1979: 28). 
više bili upućeni djelu Kultura i bosanski franjevci, zbog činjenice da autor slavonske i dalmatinske franjevce obuhvaća tim nazivom, koji u njegovo vrijeme više nema nekadašnje značenje (usp. Džaja 2008: 143-145). ${ }^{12}$ Jelenić je primjedbu uvažio praveći u naslovu svoje biobibliografije distinkciju između izraza „,bosanski franjevci” i „franjevci Bosne Srebreničke”. ${ }^{13}$

U pogledu izbora pisaca i imenovanja književnosti on slijedi svoje prethodnike, dakle Lastrića, Jukića, Matkovića. Boris Ćorić primjećuje da je to bila „ustaljena praksa franjevačke historiografije” i da su tako postupali ,i historici susjednih provincija" (Ćorić 1979: 22-23). Međutim, u Lastrićevo vrijeme, a dobrim dijelom i u 19. stoljeću, izraz „bosanski franjevci” odnosio se na provinciju Bosnu Srebrenu i njezin nekadašnji opseg. Podjelama provincije u 18. stoljeću dio koji je zadržao staro ime sveo se u granice Bosne i Hercegovine pod osmanskom upravom. U 19. stoljeću provodi se nova dioba i Hercegovina se odvaja u posebnu provinciju te se Bosna Srebrena svodi na bosanski zemljopisni prostor. Sintagma „bosanski franjevci” počinje asocirati samo na taj novi opseg pa u Jelenićevo vrijeme imenovanje korpusa postaje problematično.

Što se pristupa obradi građe tiče, premda koncentriran na pozitivne činjenice vezane za autore i djela, i Jelenić kao i njegovi prethodnici dijelom prelazi okvire žanra biobibliografije te pokazuje naznake složenijega književnopovijesnog pristupa. U svakom biobibliografskom članku dosljedno realizira trodijelnu strukturu (usp. Pavić 2008: 235), imenujući segmente kao „harakteristika”, „hronologija” i „,književni rad”. „Hronologija” pritom predstavlja biografiju u užem smislu riječi, ,književni rad” bibliografiju, a najinteresantniji je dio svake jedinice „harakteristika”.

U tom segmentu Jelenić u prvom redu izlaže činjenice vezane za jezik, izdanja djela, izvore i drugo, te ispravlja i dopunjava dotadašnje netočne ili nepotpune tvrdnje u literaturi. Rad određene osobe predstavlja u cjelini, ne usmjerujući se samo na spisateljski nego i na širi kulturni, društveni, prosvjetni ili politički angažman. Osim toga donosi i mnogo podataka o sadržajnim, žanrovskim, kompozicijskim i drugim aspektima djela. Upušta se u podosta slučajeva i u književnopovijesne analize djela i opusa. Dobar je primjer predstavljanje književnog djela Augustina Čičića, gdje Jelenić

\footnotetext{
12 Vrlo iscrpan pregled kritičkih napisa o Jelenićevu djelu donosi Boris Ćorić, podrobno analizirajući prigovore te primjećujući da motivacija nekih kritičara nije ostala u okviru struke (Ćorić 1979: 13-14).

13 I Prohaski se zamjerao „višak” pisaca u njegovoj knjizi (usp. Bogavac 1979: 69).
} 
zamjećuje poetičke veze i utjecaje (usp. Jelenić 1925: 71-75), ali se u analizi dominantno zadržava na idejnom aspektu njegove poezije. Također donosi i podosta podataka o recepciji, kako u široj publici - primjerice o Babićevu Cvitu (isto: 8), Divkovićevu djelu (isto: 84) itd. - tako osobito u stručnoj literaturi koju često citira.

Jelenić u većini slučajeva izriče i svoje vrijednosne procjene opusa i pojedinačnih djela te određuje njihova mjesta u predstavljenoj književnoj tradiciji. Tako se primjerice osvrće na vrijednosti rada Ivana Bandulavića ili Matije Divkovića (isto: 16, 84), kao i Jeronima Filipovića (isto: 95), Marka Dobretića (isto: 79-80), Bone Benića (isto: 43) i drugih. Iznosi i stavove o manjkavostima, primjerice Babićeve gramatike (isto: 7), djela Augustina Čengića, ${ }^{14}$ a osobito pak djela Rafe Barišića starijeg, kojem spočitava reakcionarnost, ali i prisvajanje tuđeg rada. ${ }^{15} \mathrm{U}$ procjeni Barišićeva rada do izražaja osobito dolazi u Bio-bibliografiji jasno izražena osobna pozicija autora i katkad vrlo snažan emocionalni odnos prema predmetu.

„Harakteristika” je, naime, a dobrim dijelom i „hronologija” (u kojoj često komentira životne okolnosti predstavljenih osoba), narativnoga karaktera, sa socijalno-političkom kontekstualizacijom života i rada osobe, ali i s izraženim dojmovima i stavovima autora. Stavovi su izraženi implicitno, kroz vrednovanje, ali često i kao očita (ne)naklonost i (ne)simpatija prema pojedinom piscu. Jelenić gotovo za svaku osobu donosi i opis karaktera te valorizaciju njezina rada. Za pojedinog će autora tako ustvrditi da je: „vrlo učevan, zaslužan i krepostan čovjek" (isto: 17), „živan i u društvu rado viđen” (isto: 33), za neke će vezati ambicioznost i umišljenost (isto: 51), „nesređen, nestalan i nemiran duh" (isto: 111). Njegove su antipatije često i opširnije artikulirane. Za Ivana će Ančića tako ustvrditi da je ,rado posjećivao Rim i svoj književni rad posvećivao rimskim crkvenim dostojanstvenicima te se

14 „Jedno je ipak, što mu dva glavna djelca ('Crkveno pjevanje' i 'Priručnu knjižicu') usko veže - konzervativnost" (isto: 68).

15 „Na književnom je polju reakcionaran. Njegova u narodu vrlo dobro primljena 'Pasha Duhovna', što ju je sastavio boraveći početkom petoga decenija prošloga stoljeća u Rimu, nosi na sebi sve osobine naše predilirske književnosti. To je prosta kompilacija latinskih molitvenika. Pa ni kao takova nije jedino njegovo djelo. Barišić sam priznaje, kako ga je pri tome pomagao tajnik mu fra Marko Kalamuti to, 'nesamo u pripisivanju, i popravljanju', nego 'i u prineshenju i sastavljanju"' (isto: 25). Jelenić isto konstatira za autorstvo „Obrane pravovijernoga i pravoslavnoga iliti rimo-katoličkoga sveštenstva i naroda u Hercegovini Turskoj”, koju također pripisuje Kalamutu i pobija autore koji je pripisuju Barišiću (isto: 26). Međutim, sva ova djela nabraja u Barišićevoj bibliografiji. 
ponosio njihovom prijaznošću i susretljivošću" (isto: 1). Sud o ličnosti pisca proteže se ponegdje i na sud o književnom radu. ${ }^{16}$ Najizrazitiji je primjer upravo članak o Rafi Barišiću starijem, u kojem Jelenić donosi opširan i vrlo nepovoljan sud o njegovu djelovanju i povijesnoj ulozi, kao i o književnom radu (isto: 21-25). Primjetno je također da više nepovoljnih ocjena donosi za novije i suvremene autore, čije djelovanje ili politički stavovi, kao u Barišićevu slučaju, imaju odjeke i u Jelenićevu vremenu. Starije pak pisce i njihov rad u pravilu vrednuje pozitivno.

U kontekstu iščitavanja ove dimenzije Jelenićeva djela, koju možemo označiti i autobiografskom, najzanimljivija je biografija Mije Batinića, Jelenićeva prethodnika u povjesničarskom poslu. Jelenić opširno (u najdužem članku u djelu) ocjenjuje njegov rad jer ga dobro poznaje, divi se Batinićevim metodama, očitujući pritom vrlo emotivan stav prema svom prethodniku i razumijevanje za teškoće koje su ga pratile: manjak izvora i pomagala, neshvaćanje poglavara i subraće, opterećenje drugim službama i nedostatak vremena (usp. isto: 34-43). Propitujući u prostoru prethodnikova života vlastitu situaciju, predstavlja Batinića kao čovjeka znanosti u uvjetima koji su znanosti neskloni, ,posve ostavljenog sebi” (isto: 39).

U svom dvosveščanom djelu Kultura i bosanski franjevci, sintezi svojih istraživanja o povijesti franjevačkog reda i njegove društvene, političke, dušobrižničke, znanstvene i kulturne djelatnosti u Bosni i Hercegovini, Jelenić je nastojao ponuditi kompleksnija književnopovijesna razmatranja. Njegove poglede na književnost i doprinos znanstvenom promišljanju povijesti književnosti u Bosni i Hercegovini najpotpunije je analizirao i vrednovao povjesničar književnosti Boris Ćorić (usp. Ćorić 1979). Njegov tekst o Jelenićevoj Kulturi ne predstavlja samo rad toj knjizi nego svojevrstan nacrt povijesti hrvatske književnosti u BiH u kojem Ćorić nudi i svoje odgovore na neka od danas otvorenih pitanja vezanih za ovu književnost, primjerice na pitanja periodizacije građe i izbora pisaca. ${ }^{17}$ Stoga Jelenićevo djelo ovdje

16 Primjerice „nestalnost” karaktera Rafe Barišića mlađeg: „Opća mana, što se opaža kod pisaca Bosne Srebreničke u mlađega se fra Rafe napose ističe. U njega manjka odmjeren i stalan smjer. Sada dopisuje u razne novine; sada se zanosi za askezu; sada piše za 'Novi Prijatelj Bosne' pripovijesti; a sada piše povijesne crtice o Kr. Sutjesci i mjesnome franjevačkome samostanu. I ove su mu crtice, po mome sudu, najvažniji dio njegova književnoga rada" (isto: 30 ).

17 Komentirajući Jelenićevo segmentiranje građe, Ćorić nudi vlastiti prijedlog periodizacije zasnovan na zapažanjima o promjenama unutar ove književnosti prije 20. st. Uočava da je, iako je za vrijeme osmanske vlasti to bila vjerska književnost, promjena u njoj ipak bilo, i primjećuje ih u 18. stoljeću. Zamjera Jeleniću što ih nije naglasio jer je ,jasno da su djelatnost 
kontekstualiziram u opisani slijed biobibliografija ne dodajući ništa bitno Ćorićevim ocjenama.

U djelu Kultura i bosanski franjevci Jelenić građu dijeli u tri razdoblja, koja su u kritici bila predmet diskusije. Prvo razdoblje čini vrijeme od dolaska franjevaca do godine 1463, drugo 1463-1780, pri čemu je gornja granica, u literaturi sporna, godina dolaska Josipa Drugog na austrijsko prijestolje. Trećem razdoblju 1780-1878. posvećen je II. svezak djela, opsegom dvostruko veći od prvoga. Struktura svakog razdoblja vrlo je slična: povijesne prilike, crkvene prilike, dušobrižnički rad, socijalno-politički rad, školstvo, znanost i umjetnost.

Iz književnopovijesnog je aspekta važan pokušaj periodizacije, koju Ćorić kritizira kao izvanjski nametnutu književnoj građi jer „Jelenić nije dosljedno pratio tok razvoja iznutra" (Ćorić 1979: 24). Važan je zatim kontekst u koji Jelenić smješta opisani književni rad te osobito konkretni dijelovi o književnosti. Jelenić je obrađuje u segmentima „znanosti i umjetnosti”. Za prva dva perioda podrobnije ih klasificira na bogosloviju, filozofiju, filologiju, povijest, pravo, liječništvo, govorništvo, muziku, slikarstvo, arhitekturu i skulpturu, dodajući im u drugom periodu pjesništvo. Za treće razdoblje Jelenić proširuje svoju klasifikaciju na nove discipline pa tako nalazimo: bogosloviju, pravo (civilno i crkveno), liječništvo, filozofiju, povijest i zemljopis, govorništvo, jezikoslovlje, lijepu književnost, sabiranje narodnih umotvorina, književna društva i časopise, kiparstvo i slikarstvo, glazbu, tiskarstvo, arhitekturu, s tim da djelatnost oko izdavanja školskih udžbenika odvaja u dio o školstvu.

i način mišljenja Filipa Lastrića bitno drukčiji od mišljenja i stava Matije Divkovića. Lastrićevo historiografsko djelovanje samo je formalno posljedica borbe oko ponovne uspostave provincije od vikarije. U suštini svojoj, novo vrijeme nametnulo je nova sredstva - borbu povijesnim argumentima" (Ćorić 1979: 26). Smatra neispitanim i to koliko djela 18. stoljeća sadrže elemente vjerskog prosvjetiteljstva, nalazeći potvrde u djelovanju biskupa Augustina Botoš-Okića, pristalice ideja Josipa II. Napominje da su biskupska pisma reflektirala suvremena europska idejna strujanja te pretpostavlja da potvrda ima i u spisima Grge Ilijića. Kao argument tezi o promjenama napominje i činjenicu da je A. Miletić plijenio Margitićeve knjige kao štetne (isto: 26). Jeleniću zamjera i što nije dovoljno pozornosti posvetio vremenu ilirskog pokreta, kad se događaju krupne promjene u djelovanju Bosne Srebrene, te ono što Ćorić prepoznaje kao sukob starih i mladih (zagovornika zaštite europskih katoličkih vladara i zagovornika ustanka i otpora). U tom kontekstu uspoređuje dva paradigmatična teksta: Barišićevu spomenicu u Beč 1837. i Jukićeve Molbe $i$ želje, koji reprezentiraju ovaj kontrast. Promjena karaktera ove književnosti i njezin naglašeno svjetovni oblik u 19. st. po Ćoriću pokazuju dubinu promjene nastale u duhovima modernih franjevaca. Književnošću se počinje smatrati samo književnost u užem smislu, a „Jelenić nije taj prijelom dovoljno naglasio” (isto: 27). 
Pritom je vidljivo da Jelenić u prvim dvama razdobljima samo pjesništvo drži književnim radom, a većinu djela koja danas držimo sastavnim dijelom ove (specifične) književnosti svrstava u bogoslovna djela: „katekizmi, katoličke dogmatike i moralke, liturgična djela, molitvenici, duhovna razmatranja i propovijedi" (Jelenić 1912: 223). Osim u odsječku o bogoslovnim, dakle teološkim djelima, i u drugim se odsječcima Jelenić bavi autorima koji se iz današnjeg aspekta ubrajaju (i) u pisce književnih djela. Tu su primjerice ljetopisci i biografi/hagiografi u odsječcima o povijesti (isto: 232-235), u trećem periodu i rad Antuna Kneževića te Ivana Franje Jukića, zatim pisci propovijedi u odsječcima o govorništvu, gdje veću pozornost posvećuje Filipu Lastriću (isto: 239-240), Marijanu Jakovljeviću, Grgi Ilijiću i Rafi Barišiću (isto: 488-489).

U predstavljanju pojedinačnih pisaca i djela do izražaja dolazi Jelenićev biobibliografski pristup (podaci o piscima, naslovi, izdanja, izvori itd.), ali gdjekad izlazi iz tih okvira, opisujući sadržaje, strukturu i druge elemente djela te mjestimice donoseći podatke o recepciji i vrijednosne sudove. Tako će naglasiti da je Ančić bio znamenit pisac (isto: 224), Lastrić plodan (isto: 226), istaknut će popularnost Babićeva Cvita u narodu te naziv „Babuša” koji je zbog toga dobio (isto: 226), kao i pastoralnu vrijednost djela Jeronima Filipovića (isto: 227) te komunikativnost Divkovićevih djela (isto: 229) i propovijedi Marijana Jakovljevića (isto: 489). Osobito zanimljivu vrijednosnu konstataciju Jelenić donosi za pjesništvo drugoga razdoblja: „Ako i nijesu ostavljeni bogzna kakovi produkti iz ove epohe, ipak je i u ovoj epohi bilo ih, koji su pjevali; a njihove se pjesme ne smiju mjeriti današnjim metrom, ni suditi prema današnjem vremenu, nego prema ondašnjemu" (isto: 241). Začetnicima pjesništva drži Matiju Divkovića i Pavla Posilovića, ističući popularnost njihovih tekstova (isto: 241).

Iz književnopovijesnog je aspekta najvrednije poglavlje „Lijepa književnost" u dijelu o znanostima i umjetnostima trećeg razdoblja, u kojem je Jelenić ponešto izišao iz svoje uloge biobibliografa. U kratkom uvodu tako iznosi nekoliko zapažanja o općim značajkama književnosti, u kojima primjećuje neke karakteristične osobine književnosti 19. stoljeća.

Najviše mjesta zauzima predstavljanje pojedinačnih autorskih opusa. U segmentima o pojedinačnim autorima Jelenić se polako upušta u književnopovijesne analize, premda najviše ostaje u okviru podataka o piscu, djelu, izdanjima, izvorima, sadržaju, te genezi nastanka i objavljivanja pojedinog djela ili problema nestanka pojedinog rukopisa (usp. Jelenić 1915: 516-517). Pritom oblino koristi postojeću literaturu i komentira sudove u njoj. U analizi 
pojedinih djela najviše se pokazuje da Kulturu nije pisao povjesničar književnosti (usp. Ćorić 1979: 33). Jelenić uglavnom ostaje na razini prepričavanja sadržaja djela, na idejnom sloju, nacionalnom ili vjerskom osjećaju izraženom u djelu, na autorovim stavovima. Prepričava tako Nedićeve budničarske stihove (Jelenić 1915: 508-512), Matićeve (isto: 530) i Josićeve latinske stihove (isto: 535-540), kao i Martićeve Osvetnike (isto: 524-527). Najviše prostora posvećuje Josiću i Martiću, kojeg drži najboljim pjesnikom ovog razdoblja. Ističe njegovu plodnost (isto: 521), ali je analiza pjesama vrlo neodređena: „Martićeva pjesma slična je luku, što se diže u vis, dosiže svoj vrhunac i obara se natrag. Ili bolje, njegov je pjesnički rad put na vrhunac mitološkoga Parnasa i salazak s vrhunca na zemlju smrtnika" (isto: 521).

Za povijest književnosti također su značajna poglavlja o skupljanju narodnih umotvorina i književnim društvima, i to zbog podataka koje Jelenić donosi, ne upuštajući se $u$ analize ili procjene važnosti predstavljenih društava i časopisa u književnopovijesnom smislu. U vrednovanju Bosanskog prijatelja poziva se na Alaupovićeve sudove (isto: 560).

Iako nije bio povjesničar književnosti, Jelenić joj je dao veliki doprinos, stvarajući vrlo široku sliku konteksta u kojem nastaje ova književnost. $\mathrm{Na}$ razini istraživanja biobibliografskih podataka Jelenić je uradio golem posao. Bio-bibliografija franjevaca Bosne Srebreničke, kao i Kultura i bosanski franjevci, važna su karika u radu na biobibliografijama ovih pisaca, ali i u razvoju znanstvene misli o hrvatskoj književnosti u BiH. U metodološkom pogledu izraz su znanstvenih shvaćanja Jelenićeva vremena. U ovim je djelima primjetno i prelaženje okvira biobibliografskog žanra, te autorovo iznošenje vlastitih pogleda na opisanu književnost i njezinu povijesnu dimenziju. U tom procesu Jelenić na svoj način pokušava riješiti različita pitanja književnopovijesne metodologije, kao što su izbor pisaca, književnopovijesni opis i vrednovanje te recepcija.

Jelenićeva je metodologija kritizirana, osobito apologetski stav prema vlastitoj zajednici i njezinoj ulozi te konzervativizam u pogledima na književnost. ${ }^{18}$ Njegove idejne okvire Boris Ćorić vidi kao prepreku razumijevanju suvremene književnosti, o kojoj je iznosio vrlo zastarjela mišljenja, napominjući da se u $\mathrm{BiH}$ u tom vremenu više nije tako mislilo ni o književnosti ni o umjetnosti (ističe kao primjer priloge u časopisu „Nada”). Međutim

18 Ćorić tako primjećuje „uskost pogleda i konzervativnost” vezan za uređivanje časopisa „Serafinski perivoj” i „Naša misao” (usp. Ćorić 1979: 13). 
cjelokupan Jelenićev rad promatra u vrlo širokom kontekstu i konstatira da je riječ o sintetskom djelu u kakvo se nitko poslije nije upustio, o golemom doprinosu istraživanju kulturne prošlosti, a na novim je istraživačima da ga nastave. Ćorićevi zaključci ostaju i danas aktualni, a Jelenićeva pak svijest o povijesti kao u prvom redu kulturnoj povijesti i dalje inspirativna. ${ }^{19}$

\section{TUGOMIR ALAUPOVIĆ}

U znanstvenom proučavanju hrvatske književnosti u BiH posebno mjesto zauzima opsežan rad Ivan Frano Jukić 1818-1857, objavljen 1907, koji je napisao slavist i klasični filolog, pisac i političar Tugomir Alaupović. Ovaj je tekst važan iz nekoliko razloga. Kao i čitav Alaupovićev rad stoji na počecima sekularizacije hrvatske kulture u Bosni i Hercegovini nakon dolaska austrougarske vlasti te laicizacije uloge pisca i znanstvenika. ${ }^{20}$ Alaupović predstavlja jednu od iznimno vrijednih pojava u formiranju novog tipa književne kritike i književnopovijesnih studija u BiH. Niz je tekstova posvetio starijim i suvremenim piscima u Bosni i Hercegovini (Jukiću, Šunjiću, Martiću, Matkoviću), prikazivao literaturu koja se o njima tada objavljivala i donosio vrlo argumentirane prosudbe o njoj.

Tekst o Ivanu Franji Jukiću, kao „najvažnije Alaupovićevo filološko djelo" (Pranjković 2004: 242), čvrsto je povezan s historiografskom i biobibliografskom tradicijom predstavljenom u ovom radu. Narativnog je karaktera, s vrlo emotivnim i angažiranim odnosom pripovjedača prema predmetu, što ga čini bliskim biografijama koje su u 19. stoljeću pisali Anto Knežević i osobito Alaupovićev učitelj u pučkoj školi Jako Matković, pisac Biobibliografie i Života o. Jakova Baltića.

Međutim, primjetno je da Alaupović u ovom djelu sa strukture biografije prelazi na strukturu književnopovijesne monografije. ${ }^{21}$ Građu tako

19 Kako zaključuje Ćorić: „Ali, na kraju, kod svakog čitanja Kulture i bosanskih franjevaca moramo se sjetiti autorova savjeta Ritigu: treba pažljivo čitati. Jer djelo sadrži više nego što se čini i kada se uzmu u obzir sve rezerve koje nam je u ruke dalo vrijeme" (1979: 33).

20 Najplodniji period s kojim ovaj proces otpočinje vrijeme je izlaženja časopisa „Nada” i Kranjčevićeva rada u Sarajevu. Alaupović je puno objavljivao u „Nadi”, a surađivao je i u uređivanju toga časopisa (usp. Pranjković 2004: 241).

21 Analizirajući ovaj rad Boris Ćorić konstatira da je Alaupović „,napisao za svoje vrijeme potpunu književnopovijesnu studiju, koja i danas služi kao osnova za proučavanje Jukićeva života i djela" (1973: 14). 
dijeli u nekoliko odsječaka. U prvom donosi podrobnu narativnu Jukićevu biografiju, s puno detalja i osobito pomno ispripovijedanim okolnostima pada u nemilost Omer-paše Latasa, progonstva i smrti. U drugom dijelu obrađuje političke i kulturne okolnosti za vrijeme Jukićeva života (prilike u Osmanskom Carstvu, u Bosni Srebrenoj, Barišićevu aferu, ulogu franjevaca u tom dobu), da bi zatim ukratko skicirao i kulturni i književni kontekst u kojem se pojavljuje Jukićev rad. Samog Jukića predstavio je kao istaknuta člana Reda, kao pisca i znanstvenika te kao zagovornika ilirskog političkog i kulturnog programa.

Tema je središnjih dijelova monografije Jukićev književni, znanstveni (zemljopisni, povijesni, književnopovijesni) i prosvjetni rad. Tu Alaupović segmentira, kronološki predstavlja, analizira te kritički vrednuje Jukićev književni i znanstveni doprinos. Osvrće se posebno na izdavanje časopisa „Bosanski prijatelj” i njegovu vrijednost, zatim na Jukićevo prikupljanje narodnih umotvorina i nedostatke toga rada. Osobito je u ovom kontekstu važno što Jukića vidi kao prvoga povjesničara hrvatske književnosti u $\mathrm{BiH}$, koji „nije imao pred sobom ništa do kratak popis pisaca iz Bosne, što ga je sastavio fra Filip Lastrić" (Alaupović 2015: 325).

Alaupović na koncu ocjenjuje da je Jukićev rad samo naoko mali i nedovršen, ali je zapravo početak ozbiljnoga znanstvenoga posla u različitim poljima te će ,slavu njegovu donijeti godine” (isto: 252). ${ }^{22}$ Strukturom rada, detaljnim analizama te argumentiranim i kritičkim valorizacijama Alaupović stoji na počecima modernih književnopovijesnih studija u Bosni i Hercegovini. Njegov se rad, potekao iz biografskih i biobibliografskih istraživanja, istodobno i udaljava od njih te najavljuje nove književnopovijesne pristupe.

Rezultatima Alaupovićevih istraživanja o Jukiću služili su se i svi kasniji istraživači (usp. Ćorić 1973: 14). U literaturi je već primijećeno da su se neka od Alaupovićevih zapažanja i sudova održala sve do danas,

22 „Istina je, da Jukić nije stvorio u svom kratkom i tako tragičnom životu ništa tako veliko, što bi u literarnoj istoriji bilo trajno. Nije bio pjesnik, a i njegovom sabiranju narodnih umotvorina može se danas koješta prigovoriti. Radio je brzo, kao da je znao, da mu je zemaljski vijek kratak. U svakom se poslu njegovom vidi hitnja pa je on opet na svim poljima prosjekao staze. Ako danas u podizanju zgrade narodne prosvjete imade i umnijih i spremnijih radenika, ne smiju se nikada zaboraviti oni, koji su prvi zemljište krčili, odnosili mulj i glib, a prosvjetne temelje natopili krvlju svojom uzidali u njih život svoj, da ih više nikakova avet porušiti ne može. Nezaslužena slava jeftina je na ljudskim jezicima, ali sa miljenikom svojim i umire. Jukićevu slavu donijet će godine pa ako smo danas što u Bosni i Hercegovini prosvjetno napredovali, od njega je početak" (Alaupović 2015: 337). 
primjerice njegovo mišljenje da pripovijetke Derviši carigradski i Dram jezika nisu narodni nego Jukićevi tekstovi, što u novije vrijeme potvrđuje i Zdenko Lešić (usp. Pranjković 2004: 244-246).

Literarni i autobiografski aspekt Alaupovićeva rada očituje se u očitom poistovjećivanju s predmetom biografije i identifikaciji s njegovom ulogom. Propitivanje vlastite (nepovoljne) pozicije znanstvenika u prostoru pisanja o znamenitom prethodniku svoj izraz dobiva već u predgovoru, gdje se Alaupović ispričava za nedostatke svoga rada objašnjavajući da radi u Sarajevu, ,gdje nema nikakove biblioteke i gdje je svaki nešto naučniji rad gotovo nemoguć" (Alaupović 2015: 251). Upravo tako predstavlja i Jukića, kao čovjeka koji je išao „neutrtom stazom” (isto: 314), artikulirajući njegov lik kao simbol gorljiva i prosvijećena čovjeka u okolnostima nasilja i opće zaostalosti. Predstavlja ga u trima ulogama: kao znanstvenika, patriota i mučenika. Propituje ih u kontekstu Jukićevih, ali bismo mogli reći i vlastitih, političkih opredjeljenja i životnoga puta ${ }^{23}$, vidjevši ga kao žrtvu spletki i zazora prema njegovim ilirskim kulturnim i političkim idejama. ${ }^{24}$

\section{ZAKLJUČNA RAZMIŠLJANJA}

Počeci znanstvenog istraživanja hrvatske književnosti u BiH vezani su za plodnu historiografsku i biografsku djelatnost u provinciji Bosni Srebrenoj u 18. i 19. stoljeću, dok se u 20. stoljeću polako od nje odvajaju i okreću prema složenijim književnopovijesnim pristupima. Radovi predstavljenih autora tako su u promatranim razdobljima usuglašeni s vladajućim znanstvenim uzusima. Lastrićev, Jukićev, Matkovićev, Batinićev i Jelenićev rad obilježava pozitivistički tip mišljenja, koji u odnosu prema književnosti svoj adekvatan oblik dobiva u biobibliografiji kao prezentaciji provjerenih činjenica vezanih za piščev život i djelo. Međutim osim što su obavljali

23 „Zbog jugoslavenske orijentacije bio je 1915. osuđen za veleizdaju i izveden pred sud, a zatim oslobođen, ali i suspendiran, pa onda umirovljen i interniran u franjevački samostan u Sarajevu. God. 1917. dolazi u Zagreb, gdje kraće vrijeme obnaša i dužnost tajnika Matice hrvatske, a zatim postaje član Narodnog vijeća Države SHS u Sarajevu. Dekretom Narodne vlade reaktiviran je pa je do 1920. ministar vjere u prvoj vladi Kraljevine SHS u Beogradu" (Pranjković 2004: 241).

24 Jukić je tako za Alaupovića „,naivan idealista, čedo sanljivih dana ilirskih” (Alaupović 2015: 268), ,prognanik i mučenik svoga visokoga zvanja” (isto: 252), neshvaćen od suvremenika i subraće, često i onemogućavan u naumima (isto: 335), prethodnik na putu: „Pa ako smo na tom putu što odmakli, ne smijemo zaboraviti, da je Jukić te puteve prosjekao i da je životom platio svoj trud i nastojanje onaj, koji je prvi pokušao poći neutrtom stazom” (isto: 314 ). 
mukotrpan posao prikupljanja i usustavljivanja podataka, u djelima se ovih autora nalaze i temelji kasnijih književnopovijesnih istraživanja iste građe.

Kod svih prezentiranih istraživača uočava se tako pokušaj rješavanja osnovnih književnopovijesnih problema. Prvi se tiče izbora pisaca koji predstavljaju opisani književni sustav. U njemu se zapaža pristup koji pripadnosti provinciji Bosni Srebrenoj daje prednost nad pripadnošću državno-političkom sustavu. Kulturu na prostoru Bosne Srebrene opisani autori shvaćaju kao jedinstvenu cjelinu, što se vidi i u obradi problema recepcije. Grgo Martić u svoj književnopovijesni pregled načelno uključuje i pravoslavni i muslimanski segment kulture u $\mathrm{BiH}$, međutim u obradi ne ostvaruje zacrtani cilj.

Kad je riječ o problemu periodizacije građe, osim u Jelenićevu djelu Kultura i bosanski franjevci, neka rješenja nalazimo već u I. F. Jukića, koji donosi rudimentaran prijedlog periodizacije, a svoj tekst ne strukturira po biobibliografskom modelu, nego po modelu tradicionalne pozitivističke povijesti književnosti.

Svi spomenuti istraživači nastoje pronaći i adekvatan način da prezentiraju odabrani opus ili djelo, te se osim iznošenja činjenica vezanih za izdanja, izvore i druge slične probleme upuštaju i u opise njegovih sadržajnih i formalnih obilježja. Pozornost posvećuju i poetičkim utjecajima, kao i pitanju recepcije, sagledavajući opisane pojave i u dijakronijskoj perspektivi. Tu perspektivu uvažavaju i u procesu vrednovanja i određivanja mjesta nečijeg djela u opisanom književnom sustavu.

Povezan s ovim historiografskim, biografskim i bibliografskim radovima, suvremeniji rad na povijesti ove književnosti nastavlja Tugomir Alaupović. Premda su zasnovani na biobibliografskom temelju, u njegovim se radovima o književnosti (i u radovima drugih njegovih suvremenika) zamjećuje kompleksniji književnopovijesni i književnokritički pristup te napuštanje biobibliografskih metodoloških okvira. ${ }^{25}$

Pogled $\mathrm{u}$ formiranje znanstvene misli o hrvatskoj književnosti u $\mathrm{BiH}$ osvjetljava nam tako povijest promišljanja i danas otvorenih i izazovnih problemskih književnopovijesnih pitanja kao što su definiranje korpusa i izbor pisaca, periodizacija, književnopovijesni opis, vrednovanje te opisivanje relacija ovog kulturnog sustava prema drugim sustavima čiji je sastavni dio.

25 Rad na biobibliografijama u 20. stoljeću dobiva svoje nastavljače. Među njima se primjerice ističu Ivan Alilović, ovdje citirani Boris Ćorić, zatim sastavljač triju antologija hrvatske književnosti u BiH Veselko Koroman, te akribični biobibliograf Anto S. Kovačić. Međutim, njihov se rad temelji na suvremenim biobibliografskim metodološkim pretpostavkama, ili se kombinira s književnopovijesnim i antologičarskim pristupom (Koroman). 


\section{LITERATURA}

Batinić, Mijo Vjenceslav. 2015. Životopis fra Augustina Miletića. Biografije bosanskih franjevaca [prir. Marko Karamatić], Sarajevo - Zagreb: Synopsis, 143-166.

Batinić, Mijo Vjenceslav. 1887. Djelovanje franjevaca u Bosni i Hercegovini za prvih šest viekova njihova boravka. Zagreb.

Beljan Kovačić, Iva. 2017. Modeli biografije u hrvatskoj književnosti Bosne i Hercegovine od 18. do 20. stoljeća. Matija Divković i kultura pisane riječi II: Zbornik radova sa znanstvenog skupa [ur. Dolores Grmača, Marijana Horvat i marko Karamatić], Sarajevo: Kulturno-povijesni institut Bosne Srebrene - Zagreb: Hrvatska sveučilišna naklada, 493-515.

Beljan, Iva. 2011. Pripovijedanje povijesti: ljetopisi bosanskih franjevaca iz 18. stoljeća. Zagreb - Sarajevo: Synopsis.

Benić, Bono. 2003. Ljetopis sutješkoga samostana. Zagreb - Sarajevo: Synopsis.

Bogavac, Mirjana. 1979. Dr Dragutin Prohaska: Das kroatisch-serbische Schrifttum in Bosnien und der Herzegowina von den Anfangen im XI bis zur nationalen Wiedergeburt im XIX Jahrhundert, Zagreb 1911. Godišnjak instituta za jezik i književnost u Sarajevu: Odjeljenje za književnost, VIII, 37-84.

Ćorić, Boris. 1973. Ogled o Ivanu Franji Jukiću. Ivan Franjo Jukić, Sabrana djela 3 [prir. Boris Ćorić], Sarajevo: Svjetlost, 9-101.

Ćorić, Boris. 1979. Književnopovijesne odlike djela Kultura i bosanski franjevci Julijana Jelenića. Godišnjak instituta za jezik i književnost u Sarajevu: Odjeljenje za književnost, VIII, 9-35.

Džaja, Srećko. 1971. Katolici u Bosni i zapadnoj Hercegovini na prijelazu iz 18. u 19. stoljeće. Zagreb: Kršćanska sadašnjost.

Džaja, Srećko M. 1974/75. Povijesno-kulturne odrednice Jelenićevih doprinosa jezičnoj i književnoj baštini Bosne i Hercegovine. Godišnjak instituta za jezik i književnost u Sarajevu: Odjeljenje za književnost, III-IV, 183-195.

Džaja, Srećko. 2008. O povijesnim pogledima i historiografskoj metodi fra Julijana Jelenića. Zbornik radova međunarodnoga znanstvenog skupa „Život i djelo dr. fra Julijana Jelenića” [ur. Ivan Markešić], Zagreb: Udruga đaka Franjevačke klasične gimnazije Visoko-Zagreb, 141-148.

Gross, Mirjana. 2001. Suvremena historiografija. Korijeni, postignuća, traganja. Zagreb: Novi Liber.

Harni, Slavko. 2008. Bibliografska obilježja Jelenićeva djela Kultura i bosanski franjevci. Zbornik radova međunarodnoga znanstvenog skupa „Život i djelo dr. fra Julijana Jelenića” [ur. Ivan Markešić], Zagreb: Udruga đaka Franjevačke klasične gimnazije Visoko-Zagreb, 217-233.

Jelenić, Julijan. 1912. Kultura i bosanski franjevci I. Sarajevo.

Jelenić, Julijan. 1915. Kultura i bosanski franjevci II. Sarajevo.

Jelenić, Julijan. 1917. Osvrt na povijesni pokret u Bosni Srebrenoj u XVII. I XVIII. stoljeću. Glasnik zemaljskog muzeja u Bosni i Hercegovini, 1-4, 1-11.

Jelenić, Julijan. 1925. Bio-bibliografija franjevaca Bosne Srebreničke I, Zagreb.

Jukić, Ivan Franjo. 1973. Sabrana djela 2 [prir. Boris Ćorić], Sarajevo: Svjetlost. 
Karamatić, Marko. 2015. Predgovor. Biografije bosanskih franjevaca [prir. Marko Karamatić], Sarajevo - Zagreb: Synopsis, 5-24.

Koselleck, Reinhardt. 1990. O raspoloživosti povijesti. „Quorum”, 4, 248-259.

Kovačić, Anto Slavko. 1991. Biobibliografija franjevaca Bosne Srebrene. Prilog povijesti hrvatske književnosti i kulture. Sarajevo: Svjetlost; Narodna i univerzitetska biblioteka Bosne i Hercegovine; Franjevački provincijalat Bosne Srebrene.

Lastrić, Filip. 2003. Pregled starina bosanske provincije. Zagreb - Sarajevo: Synopsis. Lašvanin, Nikola. 2003. Ljetopis. Zagreb - Sarajevo: Synopsis.

Martić, Grgo. 1990. Izabrana djela III. [prir. Branko Letić]. Sarajevo: Svjetlost.

Matković, Jako. 1896. Bibliografia bosanskih franjevaca. Sarajevo.

Matković, Jako. 2015. Život o. Jakova Baltića. Biografije bosanskih franjevaca [prir. Marko Karamatić], Sarajevo - Zagreb: Synopsis, 187-235.

Meić, Perina. 2010. Čitanje povijesti književnosti. Metodološki modeli književnopovijesnih istraživanja u hrvatskoj znanosti o književnosti, Mostar: Alfa.

Pavić, Stjepan, 2008. Bio-bibliografija franjevaca Bosne Srebreničke Julijana Jelenića. Zbornik radova međunarodnoga znanstvenog skupa „Život i djelo dr. fra Julijana Jelenića” [ur. Ivan Markešić], Zagreb: Udruga đaka Franjevačke klasične gimnazije Visoko-Zagreb, 235-238.

Pranjković, Ivo. 2004. Tugomir Alaupović o fra Frani Jukiću. Bosna franciscana, 20, 241-251.

Solar, Milivoj. 2006. Rječnik književnoga nazivlja. Zagreb: Golden marketing; Tehnička knjiga.

Vešara, Miroslav. 1982. Fra Mijo Vjenceslav Batinić (1846-1912). Fra Josip Markušić. Zbornik radova sa simpozija u povodu 100. obljetnice rođenja [ur. Josip Turčinović], Zagreb: Kršćanska sadašnjost - Sarajevo: Revija „Nova et vetera”, 320-345.

\section{SUMMARY}

\section{BIO(BIBLIO)GRAPHIES: THE BEGINNINGS OF THE SCIENTIFIC RESEARCH OF CROATIAN LITERATURE IN BOSNIA AND HERZEGOVINA}

This paper focuses on the beginnings of scientific research of Croatian literature in Bosnia and Herzegovina and presents biographical and bio-bibliographical work of seven authors, starting with Filip Lastric in the $18^{\text {th }}$ century to Tugomir Alaupovic in the first half of the $20^{\text {th }}$ century. We observe how these authors perceived the literature and its historical dimension, especially how they approached the basic problems of literature history, such as defining literary corpus, choice of writers, periodisation, literary-historical interpretation and validation of literary work, as well as what solutions they offered. The gradual abandonment of the bio-bibliographical framework and the application of more complex literary-historical approaches are also analysed.

Key words: biography, bio-bibliography, Croatian literature in Bosnia and Herzegovina, history of Croatian literature. 